\title{
Martin Holtz
}

\author{
Greifswald University
}

\section{THE WESTERN AND THE WAR FILM: CLINT EASTWOOD'S AMERICAN SNIPER AS GENRE HYBRID}

DOI: $10.19195 / 0860-116 X .38 .8$

\section{INTRODUCTION}

The Western and the war film have a lot in common. Both genres are concerned with the moral ramifications of using violence either in the emergence or the defense of a civilization. The Western is chronotopically at home in the North American frontier region of the nineteenth century, while the war film is concerned with the global waging of war in the twentieth century, but since both genres are thematically related, they have routinely cross-fertilized each other in various ways. Routinely, Westerns have portrayed contemporary wars in an allegorical fashion, presenting justifications or criticisms of America's military endeavors in the guise of a mythically refracted foundational moment of the nation. Conversely, war films have routinely employed the iconography or aesthetic strategies of Westerns in order to illustrate the cultural resonance of the genre's elements for the self-conception of the country in military disputes. This article seeks to explore the ways in which the two genres have interacted with each other over the years in order to understand their current relationship. By tracing their mutual interaction as a varied historical development it shall be shown how the evocation of Western elements in contemporary Iraq War films has the effect of contributing to a sense of moral ambiguity in the way military violence is portrayed, befitting a cultural climate of critical self-inspection. Clint Eastwood's controversial American Sniper (2014) will serve as an illustrative example. 


\section{WESTERNS AND WAR FILMS}

That violence is central to the Western has never been more eloquently established than by the genre's first critic, Robert Warshow. In 1954 he wrote:

Those values [of the Western] are in the image of a single man who wears a gun on his thigh. The gun tells us that he lives in a world of violence, and even that he "believes in violence." But the drama is one of self-restraint: the moment of violence must come in its own time and according to its special laws, or else it is valueless. There is little cruelty in Western movies, and little sentimentality; our eyes are not focused on the sufferings of the defeated but on the deportment of the hero. Really, it is not violence at all which is the "point" of the Western movie, but a certain image of man, a style, which expresses itself most clearly in violence. Watch a child with his toy guns and you will see: what most interests him is not (as we so much fear) the fantasy of hurting others, but to work out how a man might look when he shoots or is shot. A hero is one who looks like a hero. (47)

Warshow captures an essential concern of the genre. Its function is to establish the rules that govern the mechanisms and execution of violence. In fact, what makes the genre so appealing and ideologically persuasive is that it associates a moral execution of violence with the iconically rendered "correct" look of the hero when he performs it. Violence can only be moral if it involves restraint, even reluctance, epitomized in the golden rule that the hero never shoots first but only after the villain has drawn his gun from the holster. Moral violence must always be a proportional answer to a provocation, but that is not enough. Richard Slotkin sees the main ideological concern of the Western as establishing what he calls a "regeneration through violence." For violence to be regenerative it must be

redemptive: it must produce a transformation in human affairs that is clearly "progressive" in some sense (which will be established by the movie). Redemption can take various forms, singly or in combination, along a spectrum that would run from the purely individual redemption of the violent hero, to the redemption of some other individual whom the hero rescues, to the implied redemption of society through the violent removal of some dark threat to its further progress: the Indian, the Outlaw, the tyrannical land baron or corporation, the lingering power of older forms of proprietorship, culture and technology. (234)

The classical Western is thus concerned with justifying the execution of violence for the common good by giving it regenerative and redemptive qualities through ideologically charged plot constructions. However, an ambivalent attitude towards violence and the hero who executes it in the service of a community is a mainstay of the genre. Beginning with Cooper's Leatherstocking, the hero's capability of being violent makes him as much a necessary protector against the external threats to the community as a potentially harmful element, who shares destructive features with the villains. As long as the hero is a man of violence he can never be a full member of the community he protects. Westerns can stress the justification of violence as much as its harmfulness, usually aiming for a balance that accentuates its ambivalence. 
A similar kind of ideological tension is at work in the war film. Guy Westwell's thoughts on the function of the classical war film capture much of what Warshow and Slotkin suggest about the Western: "According to [Marxist critical discourse] the ideological function of the cultural imagination of war is to make war feel right. That is, ideology, through the deployment of a specific way of imagining war, encourages us to think of war as a productive mechanism of progressive political change tied, in this instance, to codes of honour, self-sacrifice and national esteem" (6). Classical war films are thus concerned with making the violence of war understandable, often in order to justify, rarely to condemn the way the nation deploys it (see Slocum 2). Where the classical Western deals with the moral dilemmas of a single hero, the war film focuses on (male) groups. As Jeanine Basinger has shown in her influential study, the WWII combat film, as the template for the classical war film, presents the group as a microcosm of American society (46). In the way the group deals with the precarious situation of war and subordinates personal to communal interests, it expresses the values and virtues of the American society as a whole, demonstrating the integrative potential of the experience of war and the execution of violence. As the group asserts itself against the enemy by overcoming its own differences and embracing collaboration, its violence is therefore just as regenerative as that of the Western hero (see Slocum 10; Westwell 36-37).

The ideology of regenerative violence in both the Western and the war film is dominant in the classical era around World War II and the ensuing decade. The cross-fertilizations of the genres in that era reinforce this ideological leaning. John Wayne had cultivated an image of the tough, boyish frontier hero in numerous B-Westerns and John Ford's Stagecoach (1939) when he entered the war film genre in films like Flying Tigers (1942), The Fighting Seabees (1944), and Back to Bataan (1945). By transplanting his Western persona to the far off battlefields, the films cherished a can-do pragmatism of justified, quick-on-the-draw violence against a savage enemy whilst exuding a spell of invincibility. The savagery of the enemy, as established in numerous Indian Westerns, also found expression in war films' use of the "last stand" motif. Custer's heroic fight to death against a faceless mass of onrushing Indians, featured in films like They Died with Their Boots On (1942), is echoed in Bataan (1943) and similar films about the early setbacks of American forces in the Pacific, with bayonet-wielding Japanese taking over the role of the Indians. In order to demonize the enemy and to glorify the heroes, war films thus frequently borrowed from the visual codes of the Western and its classical ideology of frontier violence to defend civilization against savagery.

The Vietnam War brought a significant change in the sentiments of Westerns and war films, which could no longer work as patriotic expressions of justified violence. The war was fiercely condemned by the majority of the young people and liberal intellectuals as a manifestation of imperialist aggression. The idea that it 
could be conceived in the same terms as World War II, namely as a war of liberation illustrating how the US is expressing and spreading its values of democracy, seemed entirely incongruent. John Wayne's The Green Berets (1968), which tried to apply the frontier scenario and Wayne's simple-minded ideology of justified retaliation to the jungles of Vietnam, was accordingly vilified or ridiculed as a demonstration of paternalist, racist, and preposterously incongruous reactionary swagger, which was no longer acceptable in a national climate characterized by social unrest, civil rights movements, and critical self-inspection. The Western significantly changed its character from functioning as a vehicle for predominantly conservative, affirmative, reassuring myths of national formation to a means of exposing the shortcomings, aberrations, and injustices involved in the "winning of the West." Films like Soldier Blue (1970), Little Big Man (1970), Ulzana's Raid (1972), and The Wild Bunch (1969) boasted critically allegorical portraits of American slaughters in Vietnam in the guise of Indian Wars and the Mexican Revolution, at a time when the war film, excepting The Green Berets, did not dare to tackle the touchy subject directly. By linking the quagmire of Vietnam to the country's inglorious westward expansion these films practiced historical revisionism, self-critically unmasking their own genre as complicit in whitewashing history. When the war film was ready to reflect on Vietnam, the resulting films took up the revisionist Westerns' strategies. Apocalypse Now (1979) stages a helicopter attack on a North Vietnamese village as a cavalry charge and its orchestrator Colonel Kilgore as a John Wayne-type cowboy, complete with cavalry hat and boots, who exudes an overbearing machismo as a lunatic manifestation of American imperialism in his desire to wipe out an entire village in order to secure a beach for surfing. Similarly, The Deer Hunter (1978) uses plot elements of The Searchers (1956) in order to portray its protagonist as a maniacally driven protector, whose desperate efforts to save his friend from the clutches of a presumed savage Vietnamese subculture of Russian roulette and bring him back to "civilization" result in his friend's death. The Western hero becomes the bringer of doom and not salvation. Western references in post-Vietnam war films remind the viewer of a misguided and failed ideological project of justifying violence in the name of civilization's advancement while emphasizing the ruthlessness and arrogance with which American culture has asserted its might on the continent and in the world.

9/11 signalled another turn for the Western and the war film alike. George Bush evoked Western rhetoric on a number of occasions in a naively reactionary way in order to underscore the moral simplicity by which the retaliation against the enemies of America would be justified. The frontier was drawn between American democracy and Middle East terrorism with the threatening claim that "either you are with us or you are with the terrorists," Bin Laden was "wanted dead or alive," and the army would "smoke out" the Taliban fighters from their mountain caves. Bush used the Western in order to cultivate a public persona of a "courageous 
man of action" and to galvanize a traumatized American (and global) public into support for his War on Terror (see Powell and Hickson 67). The first Westerns to be released after 9/11, Open Range (2003), The Alamo (2004), and The Missing (2003), followed suit and presented frontier violence as an adequate means to vanquish a perfidious enemy. Open Range even modified the cowboy code to allow for a preemptive strike, bypassing the golden rule that the hero has to wait for the villain to draw when Kevin Costner shoots an enemy point blank in a climactic shootout on main street. The first war films released in the wake of $9 / 11$ but produced before it evinced a similar notion of a return to pre-Vietnam classicism with the addition of slight modifications. Films like Black Hawk Down (2001) and We Were Soldiers (2002) transformed military disasters (Somalia, Vietnam) into displays of military values like camaraderie, professionalism, and self-sacrifice by consciously eschewing political dimensions or "causes" and evoking such Western motifs as the "last stand" in order to elevate the achievements and sacrifices of the soldiers (see Westwell 113; Young 317-320; Greiner 195-210). Yet the universally derided Iraq War and the subsequent disclosures of the Abu Ghraib and Guantanamo torture scandals quickly compromised the sudden burst of classical genre resurgence and re-introduced a revisionist turn to both the Western and the war film. ${ }^{1}$ Post-Iraq Westerns like Seraphim Falls (2006), No Country for Old Men (2007), The Proposition (2005), True Grit (2011), or Django Unchained (2012) collapse the neat frontier distinction of wilderness and civilization and suggest that civilization harbors more savagery than the wilderness, whereby they derisively comment on the war, in which Iraq was overrun by "civilization," the war was ostensibly won, "wilderness" ceased to exist, but the chaos not only remained, it grew stronger, and the despairing insight that post-Iraq Westerns deliver is that the chaos grew stronger because of civilization's triumph. By highlighting the savagery of civilization, the Western once again provides a national self-critique that exposes the country's injustices inherent in its conception. Western references in modern Iraq War films fulfill precisely that function. They evoke a disturbing, dark side to the "civilizing," ostensibly protective efforts of the American military in the Middle East. The fascination and even endorsement of war and its charismatic American representatives that recent Iraq War films like The Hurt Locker (2008), Zero Dark Thirty (2012), and particularly American Sniper ostensibly transport is undercut by the evocation of Western tropes, which have acquired unerasable

1 The earliest Iraq War-themed American films were released as early as 2003. Yet the public largely ignored these films that veered between propagandistic vehicles (e.g. Saving Jessica Lynch, 2003) and uncomfortably accusatory provocation (e.g. Redacted, 2007). It was not until the release of The Hurt Locker in 2008 that a template for Iraq War films was set, which proved to be popular with the public and critics alike. For a list and discussion of early Iraq War films see Barker, $A$ "Toxic Genre," and Carruthers, "Limited Engagement." 
revisionist undertones. How the genre persists to cast a spell of moral ambiguity over the modern war film shall be illustrated with the example of American Sniper.

\section{AMERICAN SNIPER}

Clint Eastwood's adaptation of the autobiography of Chris Kyle, "the most lethal sniper in US military history" (Kyle, front cover) is a contentious film, which has received accolades, culminating in the nomination for various Academy Awards including Best Picture, and vilifications. On the one end of the spectrum, the film has been attacked and even picketed because it allegedly "dehumanizes Muslim individuals, promotes the idea of senseless mass murder, and portrays negative and inaccurate stereotypes" (Thomason A8). Critics of the film admonish its apparent glorification of a despicable character, who killed more than 160 people in the name of protecting freedom-loving America from evil "savages" and who is even elevated into martyrdom when at the end of the film he is killed by someone he wanted to help. The film's suggestion is that America can be proud to have people like him serving the country and should pay respect to those who can kill without mercy or hesitation when its enemies become a threat. An exemplary critique reads, "Sniper is a movie whose politics are so ludicrous and idiotic that under normal circumstances it would be beneath criticism. The only thing that forces us to take it seriously is the extraordinary fact that an almost exactly similar worldview consumed the walnut-sized mind of the president who got us into the war in question" (Taibbi). On the other end of the spectrum, critics have stressed the film's ambiguous relation to its hero, seeing it as an exploration of a figure who represents America in its military incarnation: ruthless, effective, forceful, and therefore morally questionable. Rather than embracing the hero, the film displays both his fascination and his reprehensibility as mutually informing qualities. This makes it a rumination on how military effectiveness comes at the cost of pathological disruption (see Scott; Denby). The Western elements in the film are crucial in evoking a troubled generic dimension that highlights the film's ambiguous treatment of the hero. They create a distancing frame, an uncomfortable association with an outmoded way of thinking that informs the hero's predilection for violence.

The film opens with a crucial scene of ambivalence, a head-on confrontation with what the war and Chris Kyle's function in it entails. He shoots an infant boy, who is about to throw a grenade at advancing US marines. The scene is cut short in the moment he pulls the trigger, but it recurs later on in the movie, in which we learn that he not only killed the boy but also his presumed mother when she picks up the grenade from her dead son. ${ }^{2}$ Rather than justifying what is happening, the

${ }^{2}$ In the book, Kyle only shoots a woman. The film "turns the screw," as it were, to use Henry James's famous formulation, by adding the young boy into the mix, thus adding to the uncomfortable nature of the scenario. 
film asks us to consider our own moral judgment. Do we accept Kyle's action as moral necessity and hence condone the killing of the boy and his mother, or does this incident earn our moral condemnation and hence leads us to question Kyle's character or at least treat him with skeptical distance? The moral ambiguity that this scene expresses informs the entire film.

The film cuts from the moment the lethal shot is fired to a flashback of the young Chris Kyle shooting a deer under the proud auspices of his father, thereby linking the two events in a causal manner, presenting one as the explanation of the other. Kyle's father talks of Chris's "gift" for killing. He becomes the mouthpiece and indoctrinator for the ideology which informs Chris's military career, which is a pretty accurate rendition of the philosophy that pervades Lt. Col. Dave Grossman's influential book On Combat, which explores and cultivates the exceptional status of the warrior in society (see Kniebe). According to Grossman and Kyle's father, the world is divided into sheep, wolves, and sheepdogs. "Most of the people in our society are sheep. They are kind, gentle, productive creatures who can only hurt one another by accident.... We know that the sheep live in denial; that is what makes them sheep. They do not want to believe that there is evil in the world." The wolves are the embodiment of evil in the world who "feed on the sheep without mercy." "But what if you have a capacity for violence, and a deep love for your fellow citizens? Then you are a sheepdog, a warrior, someone who is walking the hero's path. Someone who can walk into the heart of darkness, into the universal human phobia, and walk out unscathed" (Grossman). Just as Chris's father, Grossman sees the capability of being violent as a gift that demands great responsibility. His glorification of the warrior is in effect an anti-liberal treatise that validates violence in the name of justice as an essentialist, universalist, and simplistic principle. Kyle's father indoctrinates his son in the philosophy of the sheepdog with violent means, threatening him with a belt should he turn into a "wolf," which encapsulates the absurdity of such a worldview, excusing any act of violence as long as the perpetrator believes it to be just. ${ }^{3}$ Kyle internalizes this philosophy, believing in the righteousness of his actions when he pummels a kid who mistreats his little brother.

As the father tells Chris of his destiny to be a sheepdog, the film cuts to the adult Kyle emerging in full cowboy gear from a stable. In this moment the parallels between the sheepdog philosophy and the frontier myth become apparent. The sheepdog correlates to the frontier hero, who protects civilization from the savagery (the sheep from the wolves), but who cannot be a full member of society because of his "gift of violence." Grossman and Kyle's father perpetuate the myth that has been a staple of the American cultural imagination for centuries. But the film not only makes clear the connection to the Western hero, but also to a particular incar-

${ }^{3}$ In a telling passage from the book, Kyle writes about the beginnings of his protective instinct: "Maybe it began because I was looking for an excuse to fight without getting into trouble" (11). 
nation of the Western hero, namely Ethan Edwards of John Ford's The Searchers, played by John Wayne. One shot recapitulates the iconic posture of John Wayne as Edwards at the end of the film, framed by a dark doorway and turning away from the door before it closes on him.

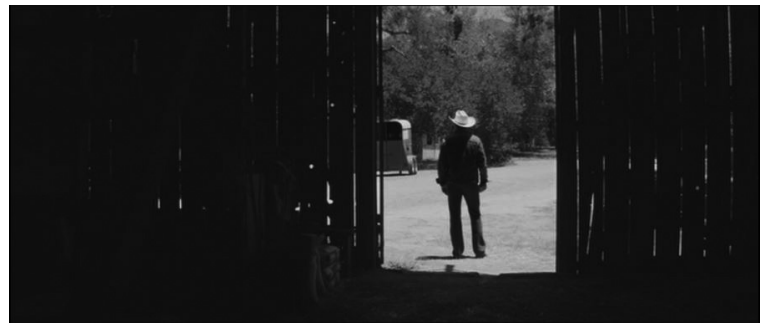

By making the visual connection to John Ford's classic, American Sniper invites a corresponding reading. Ethan Edwards is, like Chris Kyle, a highly controversial character. He is obsessed with protecting his own kin from Indian savagery and exposes a dark, violent, and racist frame of mind in the pursuit of his niece Debbie, who has been kidnapped by a Comanche band led by the half-blood chief Scar. His obsession with saving Debbie from a corruption by Indian blood is so intense that he seeks to kill her rather than allowing a mingling of the sheep with the presumed wolves and her existence as a "squaw," and even if he forcibly brings her back home at the end of the film, he is symbolically excluded from the white civilization he violently demarcated from Indian savagery by being shut out from the family home. In the end, an entire Indian village is wiped out to save a white girl who does not want to be rescued. The Searchers exposes the destructive side to the obsession with protection and the demarcation of the world into sheep and wolves. What counts for Edwards, counts for Kyle. Alas, the Western world that Kyle moves in at the beginning of the film is a perverted modern-day travesty of the rodeo. The film uses the rodeo circuit in order to point out how the frontier has been transformed into a commercialized shell of its former self, following films like The Lusty Men (1952), The Misfits (1961), Junior Bonner (1971), or Brokeback Mountain (2005). As his cheating girlfriend lets the beer drinking, day laboring Kyle know, he is not a cowboy, he is just a ranch hand. When Kyle sees footage of a terrorist attack on a U.S. government building, he realizes that in order to be a cowboy in the modern world, he should not go West but East. ${ }^{4}$ He needs to enter the military in order to satisfy his internalized sheepdog mentality.

The depiction of Kyle's military career negotiates the implications of the cowboy image he is adamant to fill out. His urge to protect is expressed on a variety of levels. When he gets to know his future wife Taya at a bar, the evening ends with her

${ }^{4}$ At the beginning of his first tour of duty, Kyle's commanding officers tells him, "Welcome to Falluja, the new Wild West of the old Middle East." 
puking on the sidewalk and him gently but firmly pulling back her hair and saying, "I got you, I got you." In numerous scenes he is seen holding her firmly in his arms as if to stress how their relationship is defined by his protective urge. Yet when he is called up for war, the country is more important than the woman. ${ }^{5}$ The experience of 9/11 as a passive spectator in front of the TV sets off a firmly internalized vengeful anger, fed by a frustration of not having been able to save his countrymen, which spirals into a "savior complex," as one of his comrades calls it. As a sniper his "job is to protect those marines at all costs," as his commanding officer puts it in the film. Sniping may upon first consideration contradict the Western code of violence as expressed in the open gun duel on main street. It is done in hiding, from a distance, without allowing the enemy a chance to draw first. In short, it is unfair. ${ }^{6}$ On the one hand, this "unfairness" constitutes a significant corruption of Kyle's incarnation of the cowboy, which becomes especially pronounced in an early montage which shows his workmanlike dispatch of numerous hapless enemies while he is tucked away in a safe spot. It is this mechanic ratcheting up of kills, which earns him the nickname "Legend," which is, as Scott points out, another heavily laden attribute in a Western context (Scott). ${ }^{7}$ Yet despite the ostensible violation of Western codes in the sniping, the film presents it in a Westernized fashion. As a sniper, more so than as a platoon member, Kyle is stylized as the lone hero, his isolation amplifying his special status as warrior and cowboy. Most important, however, is the inclusion of a villain as a counterpart mirroring the skill of the hero, who, even though he remains unseen by Kyle, is being confronted and killed in a quasi-duel in the showdown of the film. ${ }^{8}$ Hence, structurally the film follows the model of the classical Western, with its triangle constellation of hero, society/woman, and villain (see Wright 32-59) with some decisive modifications.

As in many Westerns, the relationship between the hero and the woman is a troubled one. The woman represents the society the hero wants to protect. She encapsulates what is desirable but also vulnerable about society. As a "sheep,"

5 In the book Kyle writes: "If I had to order my priorities, they would be God, Country, Family" (8).

${ }^{6}$ Around the release of the movie a tweet from Michael Moore saying "that snipers were once considered cowards and that one had killed his uncle" was met with considerable outrage by fans of the movie on the right wing of the political spectrum on Twitter (Buckleyjan). Sniping is of course also reminiscent of The Deer Hunter in which it is the hero's obsession with the one shot kill that figuratively kills his friend when he comes back to Vietnam to save him from the antithetical Russian roulette games he plays.

7 In John Ford's The Man Who Shot Liberty Valance (1962) the famous slogan "When the legend becomes fact, print the legend" is uttered by a newspaperman, pointing out the mismatch between the glorifications of historiography and the ingloriousness of reality. Kyle's status as a "legend" is similarly compromised in the film.

8 Mustafa, the villain of the film, appears in only one paragraph in the book, which ends with the statement, "I never saw him, but other snipers later killed an Iraqi sniper we think was him" (158). The film consciously constructs an individualized conflict in order to fit the genre pattern, it seems. 
however, she resists the violent ways of the hero, urging him to relinquish them. Classically, as for example in Owen Wister's novel The Virginian (1902) or in George Stevens's Shane (1953), the violence of the hero turns out to be justified because it eliminates a threat to both himself and society, which the woman comes to accept. In American Sniper, Taya is undeniably fascinated by Kyle's prowess and protectiveness, playfully displayed in their visit to a shooting gallery. Yet she is also questioning his sentiments early on, telling him that it is "pretty egotistical to think you can protect us all." When Kyle is away in the war, the tension between his obligations to his family and to the military take center stage. A recurrent feature are phone conversations between him and Taya while he is sniping or even shortly before he enters a gun battle. The phone calls are less an illustration of the deep and ongoing connection between the two than of the tenuousness of their connection. Repeatedly, their conversations are interrupted by the reality of war, and even when the war takes a break, the film stresses Kyle's constant state of alertness, never allowing the connection to his wife to disturb his military duty. What the phone conversations suggest figuratively is the distance that exists between what Kyle does in the war and its benefit for the society he set out to protect. In the classical Western there is an immediate relation between killing the villains and protecting the community. But in American Sniper the physical and emotional distance that the war creates between hero and woman suggests an implicit comment on the misguidedness of Kyle's protective efforts. The urge to protect has become detached from its communal benefits. It distances him from society rather than serving it. Even worse, whenever Kyle is home his sheepdog mentality manifests its destructive potential. His constant alertness leads him to see threats to Taya and his family everywhere, which results in a state of permanent volatility. He nervously looks in the rearview mirror, he attacks a barking dog, he yells at a nurse at the maternity ward for not taking care of his newly born daughter. All that Taya can do is to helplessly appeal to Chris to reconsider his priorities, telling him "You did your part. We've sacrificed enough. You let somebody else go.... I need you to be human again." Just as in The Searchers, the hero's obsession with the protection of (white) civilization is disrupting the very thing he is protecting.

Kyle's craving for protecting others is most strongly realized in war. In order to save his comrades, there needs to be a threat from which to save them. Throughout the film, Kyle not only seems to attract such threats, he even seems to seek them, possibly even fabricate them, leading his men into danger so that he can rescue them. It is through his "savior complex" that his unit gets involved with a particularly gruesome villain who is called "The Butcher" and whose favored torture device is a power drill. The resulting encounter leads to a fatal shootout and leaves an Iraqi family dead. Later he uncovers a weapons cache and a torture chamber, which leads his men into another shootout. His increasingly aggressive demeanor, calling the enemy "savages," sporting the skull emblem of the controversial comic 
book hero The Punisher and a pair of sunglasses as if to cloud the moral scope of his vision, ${ }^{9}$ appears to provoke greater hostility from the enemy. If the film portrays the Iraqis as one-dimensional savages (which it does not to the extent it has been criticized for doing), then this unflattering portrayal serves to illustrate the hostile perspective with which Kyle sees his surroundings. Nowhere does this become more obvious than in the depiction of the main villain, Kyle's counterpart Mustafa, an Olympic sharp shooter, who matches Kyle in his precise and effective decimation of the enemy. It is significant that the villain, though visible to the audience, is never actually seen by Kyle, nor, it seems, by anyone else in the film. It seems as if Kyle's insistence on his existence only makes him a reality. The strong mirror-image-like ties that exist between the hero and the villain are again reminiscent of The Searchers, in which the Indian chief Scar does not only bear a visual resemblance to John Wayne's Ethan, but also serves as the projection screen for his repressed desires that need to be annihilated. In American Sniper, Mustafa is the projection screen for Kyle's feelings of guilt over not being able to save every comrade, and his annihilation the compensation for his guilt. Hence, what unites the two films is the presentation of the villain as a split off alter ego of the hero, ${ }^{10}$ and the suggestion that the hero can only find redemption if he wipes out his counterpart.

The irony of course is that Kyle's desperate search for the villain is what gets his fellow soldiers killed in the first place. His comrade "Biggles" is killed by a shot in the head when Kyle leads him on a rooftop in pursuit of the enemy, and Marc, who is also called "Priest" because of his erstwhile ambition to become one, is killed in a subsequent retaliatory effort. "Priest" emerges as the most vocal critic of Kyle's doggedness in the film, which links him to the character of Martin Pawley in The Searchers, with the significant modification that Marc, as the voice of empathy, dies where Martin lives. Early on he tells Kyle, "You can't shoot what you can't see," implying an encouragement to let things go rather than adamantly insisting on the pursuit of the villain. Later on he becomes more and more disillusioned with the business of war and Kyle's obsessiveness, confronting him with the hypocrisy of carrying a Bible around with him when he asks if he has ever read it. At his funeral, his final letter is read to the attendees, in which he asks: "When does glory fade away and become a wrongful crusade or an unjustified means by which consumes one completely?" Kyle is wearing sunglasses and tells Taya that it is this kind of attitude that killed Marc.

Despite his outward steely composure, Kyle becomes increasingly affected by the war. In a scene that harkens back to the opening, he is about to shoot a small

9 The Punisher comics regularly flaunt the moral questionability of the hero's ruthless vigilante justice. The same goes for Clint Eastwood's iconic Dirty Harry films, in which the main character regularly sports sunglasses.

10 Significantly, it is Kyle who has a bounty put on his head in the film, just like the villains in Westerns, which emphasizes his duplicitous status. 
boy who picks up a rocket launcher from a soldier Kyle just killed but lets it fall just before Kyle is about to pull the trigger. His relief and visible distress over the prospect of almost having to shoot another child stands in stark contrast to the assured execution of the opening scene. But Kyle can only find peace of mind when he kills the villain, and that opportunity offers itself when he, with his unit, is sent out on a mission to kill a sniper who picks off American soldiers building the walls of a fort in hostile territory, again a highly charged Western reference to the advance of "civilization" into the "wilderness." No one knows who the sniper is, but as the commanding officer tells Kyle, "He can be whatever the fuck you need him to be," so Kyle naturally wants him to be Mustafa. The scenario takes Kyle's unit deep into enemy territory. And even though he cannot see Mustafa, the film depicts his search for him in the crosshairs, where only a faint glimmer of Mustafa's weapon betrays him (again a Western reference to the gleaming spears of Indians), as the culminating duel of two professionals. The killing of Mustafa encapsulates the central dilemma, or irony, of Kyle's savior complex. The shot he fires, though eliminating the villain from a formidable distance and being an impressive display of his skill, also alerts the other enemies to the vulnerable position of his unit. He thus puts the men he is trying to protect in danger by protecting them. The desperate firefight that ensues recapitulates the "last stand" motif, complete with a faceless and suicidal mass of onrushing attackers, and it involves another irony. Kyle, just as the rest of his troop, barely makes it out alive under cover of a sandstorm. The sandstorm can be understood as the figurative wilderness that he himself has summoned and which almost swallows him up but which turns out to give him the needed protection to get into the truck. If he endangered the men by trying to save them from savages, the savage wilderness he tried to combat ends up saving him.

The redemption of Kyle is, however, not complete with the killing of the villain. He needs to be reintegrated into the society he has protected. In the classical Western this requires the hero's renunciation of violence, often in a symbolic gesture of giving up his guns (Wright 48). In American Sniper this reintegration is crucially flawed. Kyle continues to be "haunted by the guys I couldn't save," as he says, suffering from persistent tension and high blood pressure despite a calm exterior. His psychiatrist channels his savior complex towards taking care of heavily wounded veterans, whom Kyle takes out to the shooting ranch. So Kyle does not give up the ways of violence. Instead, he infuses civilization with his predilection for it, as it were. He teaches his son the ins and outs of hunting in a scene very similar to the one showing him as a child being taught by his father, implying that he passes on the ways of violence to his son. Just before Kyle goes out to meet his own killer, who happens to be one of the veterans he looks after, he is shown dressed up as a "regular cowboy," as he says, mockingly threatening his wife with a six-shooter, playing an aggressive bear for his giggling daughter, and telling his son 
to watch out for the family as long as he is gone. By recapitulating the image of the cowboy just before we see the killer, however playfully it is performed by Kyle, the film suggests that the frontier mentality represented by the Western iconography is what kills Kyle (see Collins). The killer is merely the agent. It is the persistence in a mindset Kyle is unable or unwilling to renounce that seals his doom.

\section{CONCLUSION}

Kyle's appearance in cowboy gear at the end of the film illustrates how deeply embedded the cult of the frontier is in the American psyche. It also encapsulates why the Western remains relevant in today's times and how the way the genre creates meaning has shifted. In Robert Warshow's conception, the Western used to imagine the "correct" use of violence by a stylized look of the hero when he executes it, today the Western conveys how the obsession of "looking like a hero" exposes a history of violence that has fully realized a self-consuming destructive potential. In American Sniper, the use of Western elements makes the viewers question the ways in which the hero justifies his commitment to violence. The film exposes the misguidedness yet cultural entrenchment of the frontier mentality, its black and white thinking, its racism, its sheepdog philosophy, its cult of violence, all of which appear so reactionary because the film relies on the way the generic history of the Western has rendered them ideological failures. The trope of the lone hero, possessed by the obsession of killing the villain or confronting the violence and danger of war, unites American Sniper with other films of the Iraq War like Kathryn Bigelow's The Hurt Locker and Zero Dark Thirty, both of which also illustrate the destructiveness, recklessness, and pathological dimensions of their heroes' obsession. This Western trope has become the overriding metaphor to encapsulate the American endeavor of the Iraq War in modern war films, as it captures both the cultural heritage and the moral shortcomings that inform its motivation.

\section{WORKS CITED}

Barker, Martin. A "Toxic Genre": The Iraq War Films. Chicago: Pluto, 2011. Print.

Basinger, Jeanine. The World War II Combat Film: Anatomy of a Genre. Middletown: Wesleyan University Press, 2003. Print.

Buckleyjan, Cara. “"American Sniper' Fuels a War on the Home Front.” The New York Times. 28 Jan 2015. Web. 21 Jul 2016. http://www.nytimes.com/2015/01/29/movies/awardsseason/american-sniper-fuels-a-war-on-the-home-front.html? r $\mathrm{r}=0$.

Carruthers, Susan L. "Limited Engagement: The Iraq War on Film." The Wiley-Blackwell History of American Film: Volume IV 1976 to the Present. Ed. Cynthia Lucia, Roy Grundmann, Art Simon. Malden: Wiley-Blackwell, 2012. 472-494. Print. 
Collins, Gail. “'American Sniper’ Moral.” The New York Times. 5 Feb 2015. Web. 21 Jul 2016. http:// www.nytimes.com/2015/02/05/opinion/gail-collins-american-sniper-moral.html.

Denby, David. “Living History: 'Selma' and 'American Sniper”'. The New Yorker. 29 Dec 2014. Web. 21 Jul 2016. http://www.newyorker.com/magazine/2014/12/22/living-history.

Greiner, Rasmus. Die neuen Kriege im Film: Jugoslawien - Zentralafrika - Irak - Afghanistan. Marburg: Schüren, 2012. Print.

Grossman, David. "On Sheep, Wolves and Sheepdogs.” Killology. 2000. Web. 21 Jul 2016. http:// www.killology.com/sheep_dog.htm.

Kniebe, Tobias. “Agiles Biest.” Süddeutsche. 25 Feb 2015. Web. 21 Jul 2016. http://www.sueddeutsche.de/kultur/american-sniper-im-kino-agiles-biest-1.2364956.

Kyle, Chris (with Scott McEwen and Jim DeFelice). American Sniper: The Autobiography of the Most Lethal Sniper in U.S. Military History. New York: Harper, 2012. Print.

Powell, Larry, and Mark Hickson. "The Divine Right of Cowboys: George W. Bush, the Iraq War, and the Cowboy Code." Studies in American Culture 32.1 (2009): 65-78. Print.

Scott, A.O. 'Review: 'American Sniper,' a Clint Eastwood Film With Bradley Cooper.” The New York Times. 24 Dec 2014. Web. 21 Jul 2016. http://www.nytimes.com/2014/12/25/movies/americansniper-a-clint-eastwood-film-starring-bradley-cooper.html? $\mathrm{r}=0$.

Slocum, J. David. "General Introduction: Seeing Through American War Cinema." Hollywood and War: The Film Reader. Ed. J. David Slocum. New York: Routledge, 2006. 1-21. Print.

Slotkin, Richard. "Violence." The BFI Companion to the Western. Ed. Edward Buscombe. London: BFI, 1988. 232-236. Print.

Taibbi, Matt. “'American Sniper' Is Almost Too Dumb to Criticize. Almost.” The Rolling Stone. 21 Jan 2015. Web. 21 Jul 2016. http://www.rollingstone.com/politics/news/american-sniper-is-almosttoo-dumb-to-criticize-20150121\#ixzz4DvDNRKWp.

Thomason, Andy. “American Sniper Brings Hard Conversation to Campuses." The Chronicle of Higher Education 61.35 (2015): A8. Print.

Warshow, Robert. "Movie Chronicle: The Westerner." The Western Reader. Ed. Jim Kitses and Gregg Rickman. New York: Limelight, 1998. 35-47. Print.

Westwell, Guy. War Cinema: Hollywood on the Front Line. London and New York: Wallflower, 2006. Print.

Wright, Will. Six Guns and Society: A Structural Study of the Western. Berkeley, Los Angeles and London: University of California Press, 1975. Print.

Young, Marilyn. "In the Combat Zone." Hollywood and War: The Film Reader. Ed. J. David Slocum. 315-324. Print.

\title{
THE WESTERN AND THE WAR FILM: CLINT EASTWOOD'S AMERICAN SNIPER AS GENRE HYBRID
}

\author{
Summary
}

The article explores the similarities of Westerns and war films and the ways in which the two genres have cross-fertilized each other since World War II. Central to their similarities are their efforts to render violence as a "regenerative" (Slotkin) means to establish or defend American civilization. Since the Vietnam War, however, the Western has taken a revisionist turn, and its subsequent evocations in war films expose the frontier ideology of justified violence in the name of the advancement of American 
civilization as a failed ideological project and highlight the imperialist aggression that connects America's westward expansion with its military efforts. Using the example of Clint Eastwood's film American Sniper (2014), the article argues that the use of Western elements in contemporary films about the Iraq War adds a sense of moral ambiguity to the portrayal of the hero, who exhibits a pathological obsession with a Western image of the righteous protector of civilization that is ultimately destructive to himself and the society he wants to protect.

\title{
WESTERN A FILM WOJENNY — SNAJPER CLINTA EASTWOODA JAKO GATUNKOWA HYBRYDA
}

\begin{abstract}
Streszczenie
Artykuł jest eksploracją podobieństw między westernem a filmem wojennym i sposobów, w jakie obydwa gatunki wzajemnie się przenikały od czasu II wojny światowej. Głównym ich podobieństwem jest próba prezentowania przemocy jako „odradzającego się” (Slotkin) środka służącego ustanowieniu bądź obronie amerykańskiej cywilizacji. Jednakże od wojny wietnamskiej western przeszedł rewizjonistyczny zwrot, a jego kolejne ewokacje w filmach wojennych eksponują ideologię Pogranicza będącą usprawiedliwieniem przemocy w imię zaawansowania amerykańskiej cywilizacji jako projektu ideologicznego upadłego i ukazują imperialistyczną agresję, która łączy amerykańską ekspansję na zachód z jej militarnymi wysiłkami. Na przykładzie Snajpera Clinta Eastwooda (2014) niniejszy esej przekonuje, że zastosowanie westernowych elementów we współczesnych filmach o irackiej wojnie przydaje moralnej dwuznaczności portretowi bohatera, przejawiającego patologiczną obsesję westernowym image'em prawego obrońcy cywilizacji, skrajnie destrukcyjnego wobec siebie oraz społeczeństwa, które chce osłaniać.
\end{abstract}

Przet. Kordian Bobowski 